\title{
Role Of Phonetic Borrowing In The Formation Of Medical Terms In The Chinese Language
}

\author{
Lola Akmalovna Sultanova \\ Senior Lecturer, Department Of Chinese Philology, Faculty Of Chinese Studies, Tashkent State \\ University Of Oriental Studies, Tashkent, Uzbekistan
}

Copyright: Original content from this work may be used under the terms of the creative commons attributes 4.0 licence.

\section{ABSTRACT}

Many elements of foreign languages have been incorporated into Chinese throughout its long history. However, the issue of borrowing from a foreign language in Chinese is of great interest. The study of this problem, along with the theoretical, is of great practical importance. Ignorance of the methods of borrowing foreign vocabulary, its features and structure, the inability to distinguish sound borrowing from words of Chinese origin quite often confuses the translator and leads to semantic errors. Borrowing vocabulary can occur verbally (phonetic) and written (semantic). Loans in Chinese can be of four types: phonetic; semantic; semi-semantic, semi-phonetic; hybrid type, where elements of both languages are present. This article discusses the types of phonetic borrowing and their role in the formation of medical terminology in the Chinese language.

\section{KEYWORDS}

Borrowed vocabulary, medical terminology, phonetic borrowing, semantic borrowing, calc.

\section{INTRODUCTION}

During the entire long history of its existence, a large number of foreign language elements penetrated into the Chinese language. Although foreign borrowings in the Chinese language are increasing every day, it is not as large as in Russian and other languages. The uneven development of scientific and technical sciences in different countries, the need to promote new concepts and candidates for advanced international relations make 
borrowing foreign words one of the most important sources of filling the lexical structure of any language. However, the question of foreign language borrowings in the Chinese language is of considerable interest. The study of this problem, along with the theoretical, is of great practical importance. Ignorance of the methods of borrowing foreign vocabulary, its features and structure, the inability to distinguish sound borrowing from words of Chinese origin quite often confuses the translator and leads to semantic errors.

\section{THE MAIN FINDINGS AND RESULTS}

In the medical terminology of modern Chinese, there is a significant number of terms borrowed from other languages, mainly from English. First of all, by borrowing we mean the process of transferring different words from a foreign language to the NKL. Borrowing vocabulary is a consequence of the rapprochement of peoples on the basis of economic, political, scientific cultural ties. In most cases, borrowed words enter the language as a means to denote new things and to express previously unknown names of already known objects and phenomena. This happens if a borrowed word is used for a slightly different characteristic of an object, if it is a generally accepted international term, or if foreign words are forcibly introduced into the language (during military occupation or the imposition of a new religion). [. http://5ka.su/ref/literature/o_ _object 39535.htmil]

The specificity of borrowing lies in the fact that the word is borrowed "not entirely as a complete, complete, grammatically formed word, but only, so to speak, as a more or less formless piece of lexical material, which receives a new design only in the system and by means of another language, the language that borrowed" . [Smirnitsky A.I. 1966, -p. 235]

Borrowing is an active process: the borrowing language does not passively perceive someone else's word, but one way or another alters it and includes it in the network of its internal systemic relations.

Borrowing vocabulary can occur verbally (phonetic) and written (semantic). In the case of orally borrowed words, words are more quickly assimilated into the language. Words borrowed in writing retain their phonetic, spelling and grammatical features longer. The activity of the borrowing language appears most clearly in the processes of semantic borrowing (tracing). But even with phonetic borrowing, it manifests itself quite clearly. First, all the phonemes in the foreign word are replaced by their own phonemes, which are the closest to the auditory impression; according to the laws of the borrowing language, the syllable structure, type and place of stress, etc. change. Secondly, the borrowed word is included in the morphological system of semantic connections and oppositions that are present in the borrowing language, is included in one or another semantic field or, in the case of polysemy, in several fields.

There are four types of loanwords in Chinese:

- Phonetic;

- Semantic;

- Semi-semantic, semi-phonetic;

- Hybrid type, where elements of both languages are present. Here sound and meaning are conveyed in translation.

Phonetic borrowing is a change in the sound appearance of words in accordance with the laws of the receiving language, i.e. these are words that, when transferred into Chinese, retain both the meaning and the form of the word of the source language.

The phonetic method is used whenever the semantic method of transmitting a foreign word is insufficient and imprecisely conveys its meaning. However, the phonetic structure of the Chinese language creates great difficulties for sound reproduction of foreign words. This, in turn, sharply limits the penetration of 
phonetic borrowings from languages where there is a different combination of sounds than in Chinese. [Ivanov V.V. 1973, -p. 59.] Therefore, such phonetic borrowings, in which the syllables in the composition of sounds coincide with the syllables of the Chinese language, or in which the combination of sounds are similar to the combinations of sounds found in the syllables of the Chinese language, or which the Chinese language is able to adapt to its phonetic system. The second reason preventing the widespread penetration of phonetic borrowings is the Chinese writing system. In cases where it is necessary to write down a borrowed foreign word in the Chinese language, such hieroglyphs are usually selected that either give a meaningless combination, or in themselves do not cause any associations with any particular material meaning. As such, particles are used, service elements, now not used, old words that can successfully record foreign words corresponding in sound. Another problem is that the reading of hieroglyphs can be different in different areas, as well as depending on dialects.

And yet the greatest number of phonetic borrowings falls on special scientific and technical terminology. They play an important role in the formation of Chinese scientific terminology. That is why pharmacology and medicine, where a significant number of nonetymologized terms and names are used, give the largest percentage of such borrowings. For instance:

普洛名 [pǔluō míng] - promin;

虎列拉 [hǔ liè lā] - cholera;

欧芹酚 [Ōu qín fēn] - ostenol;

拖拉火姆 [tuōlā huǒ mǔ] - trachoma;

尼古丁 [nígǔding ] - nicotine ;

噻唑 [sāi zuò] - thiazole;
Phonetic mastery is complete, incomplete, partial. Full mastery is observed when the soundings of the word match in the source language and the borrowing language (Chinese): [Ivanov V.V. 1973, -p.63.]

非丁 [fēidīn - phytin;

尼奥平 [niàopíng] - neopine;

Incomplete development takes place in cases when the sound of a foreign is possible in the Chinese language when borrowing (one or two vowels or consonants are modified or the final consonant drops out):

大仓丁 [dàlúndīng ] - dilantin;

尼拉汀 [nílātīng ] - neraltein;

With partial mastering, the sound of borrowed words in the Chinese language only approaches the sound or remotely resembles the sound of the words of the source language (both consonants and vowels are modified, a vowel is added to the consonants of the source language):

卡托普利 [kātuōpǔlì] - captopril;

普利米酮 [pǔlǐmǐtóng] - primidon;

Frolova O.P. subdivides phonetic borrowing into purely phonetic and semi-phonetic. [Frolova OP, 1981] Purely phonetic borrowing in medical terminology is, as a rule, substances and drugs:

卡波卡因 [kăbōkăyīn] - carbocaine;

加菲因 [kāfēiyīn] - caffeine, trimethylxanthine;

Moreover, some have a synonymous series of semantic borrowing:

荷尔蒙 [hèěrměng ] = 激素 [jisu] - hormone;

维他命 [wéitāmìng] = 维生素 [weishengsu] vitamin;

Some with two spellings; 
阿摩尼亚 [āmóníyà] = 亚摩尼亚 [yamoniya] ammonium;

可卡因 [kěkăyīn ] = 古柯因 [gukeyin] - cocaine;

Semi-phonetic borrowing - terms created by combining foreign language material with Chinese, that is, one part of the term is transmitted according to the rules of phonetic transcription, and the other through a morpheme carrying its own meaning:

爱克斯光 [àikèsīguăng] - X - rays

(爱克斯- [aikesi] - from english.X-irs);

埃可病毒 [āikěbìngdú ] - ECHO viruses;

Semi-phonetic borrowings can be of two types: 1) formed by the type: phonetic borrowing + word-formation element:

阿洪病 [āhóngbìng ] - aigum, anyum;

卡法根 [kăfăgēn] - kava;

2) formed by the type: word-formation element + phonetic borrowing:

伪可卡因 [wěikěkěyīn ] - pseudococaine (伪 [ wei]-“false, pseudo” +可卡因 [kekayin];

内阿米巴 [nèiāmìbā ] - entameba; (内 [nei] - “ internal, endo"+ 啊米巴 [amiba]);

Family terms with foreign names also refer to semi-phonetic borrowings: 阿尔茨海默氏病 [ā ěr cí hăi mò shì bìng ] - Alzheimer's disease, presenil new dementia;

奥本海姆氏反射 [Ào běn hăi mǔ shì fănshè ] Oppenheim reflex;

\section{CONCLUSION}

It should be noted that in the Chinese language, many phonetic borrowings are represented by semantically filled syllables. Borrowed words, while remaining phonetic borrowings of various types, receive a kind of meaning that corresponds to the proper meaning of their syllables. At the same time, it cannot be assumed that they are traced, since they still, to one degree or another, reflect the sound of words in the source language:

朋带[băngdài] - bandage (eng.bandage) = 绑 [ bang] - “to bind" +带 - [dai] - “tape";

维他命 [wéitāmìng ] - vitamin = 维 [wei] “store" +他[ta] - “he"+命[ming] - "a life";

From all of the above, it follows:

- There are four types of borrowing in the Chinese language: phonetic, semantic, semi-semantic, hybrid.

- Phonetic sound shell of a foreign word.

- Many borrowings - borrowings of external phonetic borrowings are represented by semantically filled syllables.

- Phonetic mastering is complete, incomplete, partial.

- Allocate purely phonetic and semiphonetic borrowing

- The largest number of phonetic borrowings falls on special scientific and technical terminology, in particular, pharmacology and medicine.

\section{REFERENCES}

1. Smirnitsky A.I. Lexicology of the English language. Moscow: 1966.

2. Ivanov V.V. Terminology and Borrowings in Modern Chinese. 1973.

3. Frolova O.P. Word formation in the terminological vocabulary of the modern Chinese language. 1981.

4. Sultanova L.A. 《汉乌俄医学小词典》. Chinese-Uzbek-Russian dictionary of medical terms. ToshDSHI, 2012.B. 315.

5. 汉俄医学大词典-北京。人民卫生出版社 。2006年。1763页。

6. http://5ka.su/ref/literature/o_ _object 39535.htmil 